\title{
EFFECT OF DIFFERENT BIOLOGICAL CONTROL AGENTS ON CURVULARIA LUNATA AND FUSARIUM MONILIFORME, CAUSING GRAIN DISCOLOURATION OF PADDY.
}

\author{
Debadatta B. Pratap; Bitish K. Nayak; Ranjan K. Jena; and Pradosh K. Jena
}

Institute of Agriculture Science, SOADU, Bhubaneswar

DOI: 10.46609/IJAER.2020.v06i03.014 URL: https://doi.org/10.46609/IJAER.2020.v06i03.014

\begin{abstract}
Grain discolouration is an important constraint in reducing productivity of rice. Curvularia lunata and Fusarium moniliorme are two important pathogens responsible for it. An in vitro study was undertaken to test the efficacy of different bio control agents against these pathogens. It revealed from the experiment that all the antagonists recorded a significant inhibition over control. Trichoderma harzianum recorded maximum mycellial inhibition of $90 \%$ followed by Trichoderma viridae (strain2) (87.44\%) and T. viridae (strain1) (83.77\%) against Curvularia lunata. In case of Fusarium moniliforme, maximum inhibition was recorded in Trichoderma viridae (strain2) (65\%) followed by T. viridae (strain1) (52\%).
\end{abstract}

Keywords: Biological control agents, Grain discolouration, Curvularia lunata, Fusarium moniliforme, Trichoderma.

\section{INTRODUCTION}

Rice is a widely distributed crop. It is cultivated in 114 countries across world, occupying a total area of 150 million hectares. Rice is staple food in many parts of the world. Apart from main food, it can be used for preparations of beverages, noodles, puffed (or popped) and beaten rice. Broken rice is used in brewing, distilling and in the manufacture of starch and rice flour. Hulls are used as fuel, packing material, industrial grinding and fertilizer manufacture. The straw is used for feed, livestock bedding, roof thatching, mats, garments, packing material and broom straws. The by-products of milling, including bran and rice polish are used as livestock feed. Oil extracted from the bran was used for both food and industrial uses. There are many factors which are responsible for low production of rice. According to Arshad et al. (2009), rice crop is attacked by more than 50 diseases which may appear at any growth stage of the plants. Out of which grain discolouration is important. A large number of fungi and bacteria are associated with it (Ou, 1985). Out of which Curvularia lunata, Alternaria alternata, Fusarium moniliformae and 
Helminthosporium oryzae are commonly found (Ou, 1985). For its management, conventional use of chemical fungicides is an appropriate and easy method to practice but it may disrupt the ecological balance and may develop resistant strains. Considering the adverse effects of it, a better and possible alternative is needed which can be economical as well as eco-friendly. To meet the demand biological control agent can be a better option. Keeping these things in mind an experiment was under taken to explore efficacy of biological control agents against seed discolouration of paddy.

\section{MATERIAL METHODS}

\section{Collection and isolation of pathogen from disease sample}

Paddy seed samples were collected from paddy fields of Central farm, OUAT, Bhubaneswar and brought to laboratory. After proper observation, seed samples were placed in moist chamber aseptically and incubated for 5 days. The mycellial growth develop from the seed were observed under microscope after proper mounting. Curvularia lunata and Fusarium moniliforme were the pathogen identified from the sample. The pathogens were brought to pure culture using potato dextrose agar medium and maintained properly.

\section{Collection and maintenance of biological control agents}

Different strains of Trichoderma were collected from various sources and maintained in potato dextrose agar medium. For each experiment, seven days old pure culture was used.

\section{Evaluation of bio-control agents against test pathogens in vitro}

Four different strains of Trichoderma were tested against the test pathogens to know their bio efficacies in vitro using dual culture technique. Twenty $\mathrm{ml}$ of sterilized and cooled potato dextrose agar media was poured into sterilized petridishes and allowed to solidify. Fungal antagonists were inoculated at one side of Petriplate and the test pathogen was inoculated at exactly opposite side of the same plate leaving 3-4 cm gap. For this, actively growing cultures were used. Each treatment was replicated four times. After required period of incubation, the radial growth of pathogen was measured and per cent growth inhibition over control was calculated by using formula given by Vincent (1947).

$$
\mathrm{I}=\frac{(\mathrm{C}-\mathrm{T})}{\mathrm{C}} \times 100
$$

Where,

$\mathrm{I}=$ Per cent inhibition of mycelium

$\mathrm{C}=$ Growth of mycelium in control 
$\mathrm{T}=$ Growth of mycelium in treatment

\section{Statistical analysis}

The experiment was laid in completely randomized block design with five treatments and four replications. The differences between treatments were evaluated by analysis of variance (ANOVA) using OPSTAT statistical software (CCS HAU, Hisar).

\section{RESULTS AND DISCUSSION}

\section{Efficacy of bio-control agents against Curvularia lunata}

The growth of the pathogen was significantly checked over control by the antagonistic nature of all the bio-control agents tested. The antagonists were also restricted the growth of the pathogen and didn't allow it to grow further. Regarding the degree of growth inhibition, maximum growth inhibition was recorded in Trichoderma harzianum(90\%) followed by T.viridae (strain1) and $T$. viridae (strain2) but inhibition of pathogen with Trichoderma sp. (strain3) was relatively least among all the antagonists. The range of growth inhibition was from $82.22 \%$ to $90.00 \%$ which undoubtedly checking the growth of pathogen without treatment with fungicides. All the antagonists resulted more than $80 \%$ of growth inhibition (Table 1 and Figure 1).

Table 1: Bioassay of Trichoderma strains against Curvularia lunata and Fusarium moniliformae

\begin{tabular}{|c|c|c|c|c|}
\hline $\begin{array}{l}\text { Sl. } \\
\text { No. }\end{array}$ & Treatments & Bio Control agents & $\begin{array}{l}\% \text { inhibition of } \\
\text { Curvularia lunata over } \\
\text { control }\end{array}$ & $\begin{array}{l}\text { \% inhibition of } \\
\text { Fusarium } \\
\text { moniliformae over } \\
\text { control }\end{array}$ \\
\hline 1 & $\mathrm{~T}_{1}$ & Trichoderma harzianum & 90.00 & 30.00 \\
\hline 2 & $\mathrm{~T}_{2}$ & $\begin{array}{c}\text { Trichoderma } \\
\text { viridae(strain1) }\end{array}$ & 83.77 & 52.00 \\
\hline 3 & $\mathrm{~T}_{3}$ & $\begin{array}{c}\text { Trichoderma } \\
\text { viridae(strain2) }\end{array}$ & 87.44 & 65.00 \\
\hline 4 & $\mathrm{~T}_{4}$ & Trichoderm.sp (strain3) & 82.22 & 32.00 \\
\hline 5 & $\mathrm{~T}_{5}$ & Control & 0.00 & 0.00 \\
\hline & & $\mathrm{SE}(\mathrm{m}) \pm$ & 0.113 & 0.04 \\
\hline & & $\mathrm{CD}(0.01)$ & 0.36 & 0.13 \\
\hline
\end{tabular}



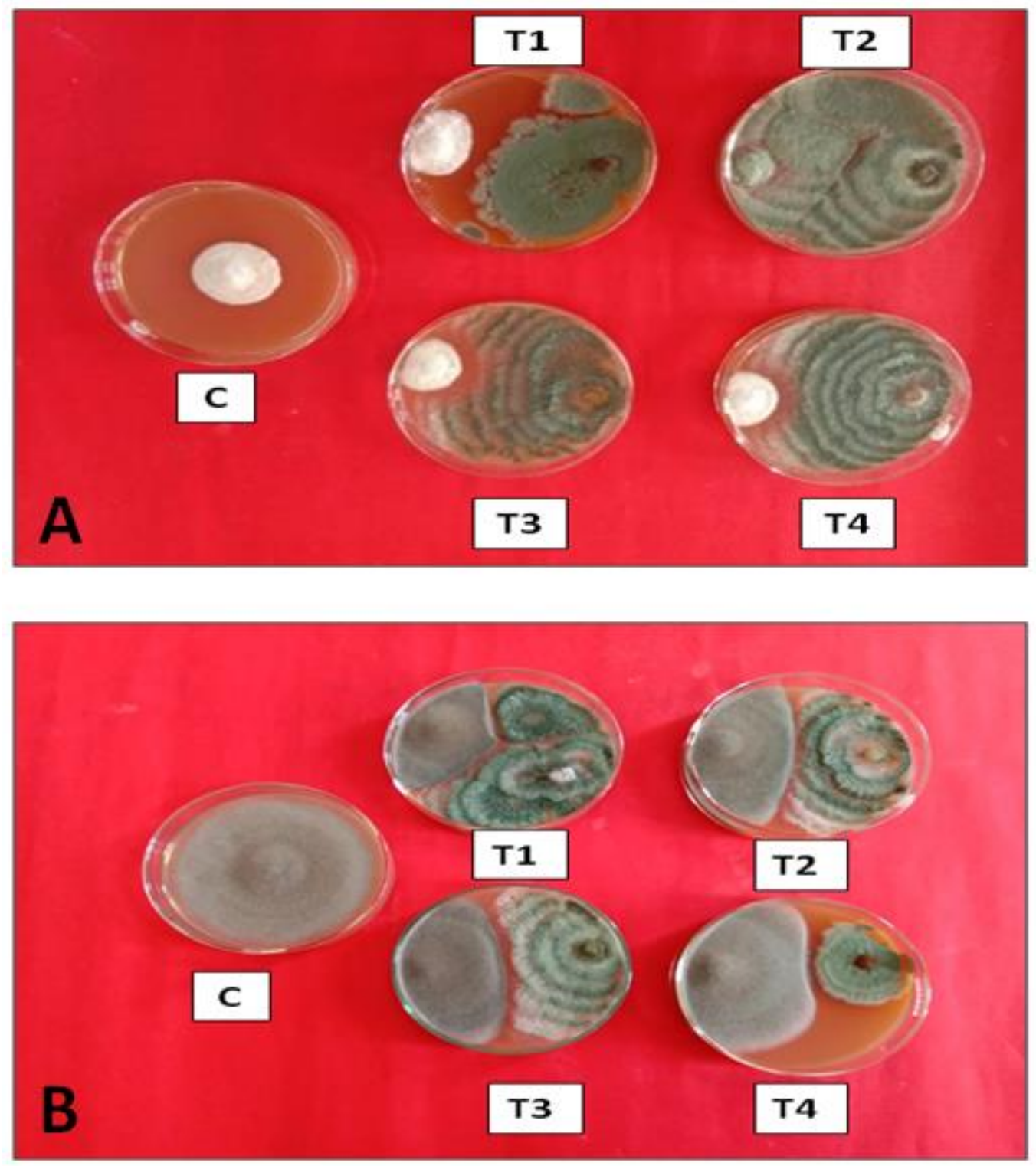

Fig1: Effect of biocontrol agent against (A) Fusarium (B) Curvularia, C: Control, T1: Tricodermaharzianum, T2: Tricodermaviride (Strain1), T3: T. viride(Strain2), T4: T.viride (Strain3)

\section{Efficacy of bio-control agents against Fusarium moniliformae}

The growth of the Fusarium was significantly checked over control by the antagonistic nature of all the antagonists tested. Maximum growth inhibition of Fusarium was observed in Trichoderma viridae (strain2)(65.00\%) followed by $T$. viridae (strain1)and Trichoderma $s p$. (strain3) recording $52 \%$ and $32 \%$ respectively which were significantly different from each other 
International Journal of Agriculture and Environmental Research

ISSN: 2455-6939

Volume: 06, Issue: 03 "May-June 2020"

but $T$. harzianum recorded least mycelia growth inhibition(30.00\%). The range of growth inhibition over control was from $30-65 \%$.

The effectiveness of Trichoderma on seed borne diseases was earlier reported by Nahere et al. (2016) and Koulagi (2011).Biological control agent such as Trichoderma can be used as seed treating agents which results into higher germination, better plant stand, less disease incidence and higher yield of different crops (Naher et al., 2016). The bio control agents like Bacillus subtilis, Trichoderma viride, $T$. harzianum inhibited radial growth of Curvularia lunata, a causal agent of gain discoloration in rice by $97.77 \%, 96.44 \%$ and $93.50 \%$ respectively but seed treatment with $T$. viride recorded highest germination per cent of 90.50 and vigour index of 1170.00(Sumangala et al, 2008) Bacillus subtilis, Trichoderma viride and T. harzianum were effective against Curvulara lunata, a causal agent of grain discolouration in rice. Seed treatment with $T$. viride was found to inhibit $C$. lunata with 90.05 per cent germination and 1170.00 vigour index followed by Bacillus subtilis $87.99 \%$ germination and 989.11 vigour index(Koulagi et al, 2011). Biological control agents like Pseudomonas fluorescens, Trichoderma viride and fungicide carbendazim found significantly reduced the disease intensity of Curvularia lunata as comparison to check plot after 90 days of transplanting (Kamaluddeen et al, 2014). Zope et .al, (2012) tested effect of Trichoderma viride, T. hamatum, T. harzianum, T. koningii, T. lignorum, Aspergillus niger and Pseudomonas fluorescens on Curvularia sp., Fusarium moniliformae and Trichoconis padwickii. The bio-agents $P$. fluorescens and $T$. koningii positively increased shoot length.

These findings are in confirmation with present results. This is a very preliminary experiment to explore the efficacy of different biological control agents against common pathogen responsible for grain discolouration. Further experiments are yet to be carried out to observe its efficacy in field which will be helpful for the farming community.

\section{REFERENCES}

Arshad H. 2009. Grain discoloration disease complex, A new threat for rice crop and its management, Pakistan Journal Phytopathol, 21(1): 31-36.

Koulagi S. 2011. Evaluations of bio-agents against Curvularia lanata, a causal agent of grain discoloration of rice, International Journal of Plant Protection, 4(2): 260-262.

Naher L, Ali MA and Sheheli S. 2016. Effect of seed treatment on seed born fungi of rice, Progressive Agriculture, 27(1): 48-56.

Ou SH. 1985. Rice disease, 2nd Edition. Commonwealth Mycology Institute, Surrey, England. 380pp. 
Sumangala, K., Patil, M. B., Nargund, V. B., Ramegowda, G. 2008. Evaluation of fungicides, botanicals and bio agents against Curvularia lunata, a causal agent of grain disolouration in rice. Journal of Plant disease sciences, 3(2): 159-164.

Kamaluddeen, Simon Sobita, Lal Abhilash A., Singh Shivam.2014. Efficacy of bio-agents and carbendazim against blight disease (Curvularia lunata) of Paddy. Annals of Plant Protection Sciences, 22(1): 152-154.

Zope A.V., Bainade P.S., Thrimurty V.S. 2012. Effect of bio-agents on seed and rhizosphere microflora of rice. Bioinfolet, 9(4): 511-516. 